\title{
Using a Balanced Scorecard Approach to Measure Environmental Performance: A Proposed Model
}

\author{
Inaam M. Al-Zwyalif ${ }^{1}$ \\ ${ }^{1}$ Faculty of Economics and Administrative Sciences, Al-Zaytoonah University of Jordan, Jordan \\ Correspondence: Inaam M. Al-Zwyalif, Faculty of Economics and Administrative Sciences, Al-Zaytoonah \\ University of Jordan, P. O. Box 130, Amman 11733, Jordan. Tel: 962-6-429-1511. E-mail: i.zwyalif@zuj.edu.jo
}

Received: June 4, 2017

Accepted: June 30, 2017

Online Published: July 10, 2017

doi:10.5539/ijef.v9n8p118

URL: https://doi.org/10.5539/ijef.v9n8p118

\begin{abstract}
Environmental aspects have been recognized by today's organizations as the most important components of value creation that would contribute to the achievement of the goals and success in the future. The purpose of this study is to propose an Environmental Balanced Scorecard (EBSC) model to evaluate environmental performance in business organizations. It also aims to illustrate how the environmental performance aspects can integrate into the Balanced Scorecard (BSC). To achieve the goals of the study, the descriptive analytical approach was adopted for its suitability for the purpose of the study. An EBSC model was developed to evaluate environmental performance with proposed four perspectives and environmental strategic objectives within each perspective. The four perspectives are the customer, internal process, learning and growth and financial. The proposed model will help managers not only to evaluate the environmental performance, but also to plan, manage and control organization's environmental activities. In addition, it can serve as a template for the organizations which aims to create environmental awareness and pursue environmental sustainability.
\end{abstract}

Keywords: environmental performance, evaluation, balanced scorecard

\section{Introduction}

In recent years, the environmental impact of business organizations has been recognized as a serious problem due to increasing pollution, legislation, and stakeholders pressure to fulfill environmental protection requirements and standards. Therefore, environmental performance evaluation has become the vital and indispensable aspect of today's organizations. So, many environmental management systems have been proposed to deal with environmental performance. One of the popular performance measurement tools, the BSC, integrates measures derived from strategy.

In this context, the objective of this paper is to propose an EBSC model to evaluate environmental performance in organizations. It also aims to illustrate how the environmental performance aspects can integrate into the BSC. The remainder of the paper is organized as follows. The next section provides the theoretical background and briefly reviews the previous literature addressing the performance measurement with the BSC, environmental performance evaluation and integration of the environmental indicators into the BSC. Then, the third section describes the research Methodology. After there, the fourth section proposes an EBSC for environmental performance evaluation. Finally, the last section presents the summary and conclusions.

\section{Theoretical Background and Literature Review}

\subsection{Balanced Scorecard Model}

Prior to the 1980s management accounting control system tended to focus mainly on financial measures of performance and ignore other important variables which were necessary to compete in the global competitive environment that emerged during the 1980s. Therefore, during the 1980s much greater emphasis was given to incorporate into the management reporting system those non-financial performance measures that provided feedback on the key variables that are required to compete successfully in a global economic environment. The need to link financial and non-financial measures of performance and identify key performance measures led to emergence of the balance scorecard (Drury, 2001). The balanced scorecard was devised by Kaplan and Norton (1992) and refined in later publications (Kaplan \& Norton, 1993; 1996a, 1996b, 2000). The balanced scorecard is a performance - measurement approach that uses both financial and nonfinancial measures to evaluate all 
aspect of an organization's operations in an integrated fashion. The performance measures are linked in a cause and-effect fashion to ensure that they all tie to the organization's overall objectives (Weygandt, 2012). Performance measures used in the balanced scorecard approach tend to fall into four perspectives, figure (1), (Atkison et al., 2007):

- Financial perspective: the financial perspective contains objectives and measures that represent the ultimate success measures for profit -maximizing companies. Financial performance measures indicate whether the company's strategy and its implementation are delivering increase in shareholder value.

- Customer perspective: the customer perspective should describe how company intends to differentiate itself from competitors to attract, retain, and deepen relationships with target customers. This perspective should reflect the heart of the strategy; it should contain specific objectives and measures for the strategy's customer value proposition.

- Internal process perspective: the internal process perspective identifies the critical operating, customer management, innovation, and regulatory and social process in which the organization must excel to achieve its customer, revenue growth, and profitability objectives.

- Learning and growth perspective: the learning and growth perspective identifies the objectives for the people, systems, and organizational alignment that create long-term growth and improvement. The objectives of this perspective emphasize the employee capabilities and skills, technology, and organizational alignment.

The balanced scorecard is a strategic management system that translates the vision and strategy of an organization into operational objectives for each of four perspectives and then establishes specific performance measures for each of the objectives.

Kaplan and Norton describe how innovative companies are using the measurement focus of the scorecard to accomplish the following critical management processes (Drury, 2001):

- Clarifying and translating vision and strategy into specific strategic objectives and identifying the critical drivers of the strategic objectives.

- Communicating and linking strategic objectives and measures. Ideally, once all the employees understand the high level objectives and measures, they should establish local objectives that support the business unit's global strategy.

- Planning, setting targets, and aligning strategic initiatives. Such target should be over a 3-5 year period broken down on a yearly basis so that progression target can be set for assessing the progress that is being made towards achieving the longer-term target.

- Enhancing strategic feedback and learning so that managers can monitor and adjust the implementation of their strategy, and, if necessary, make fundamental changes to the strategy itself.

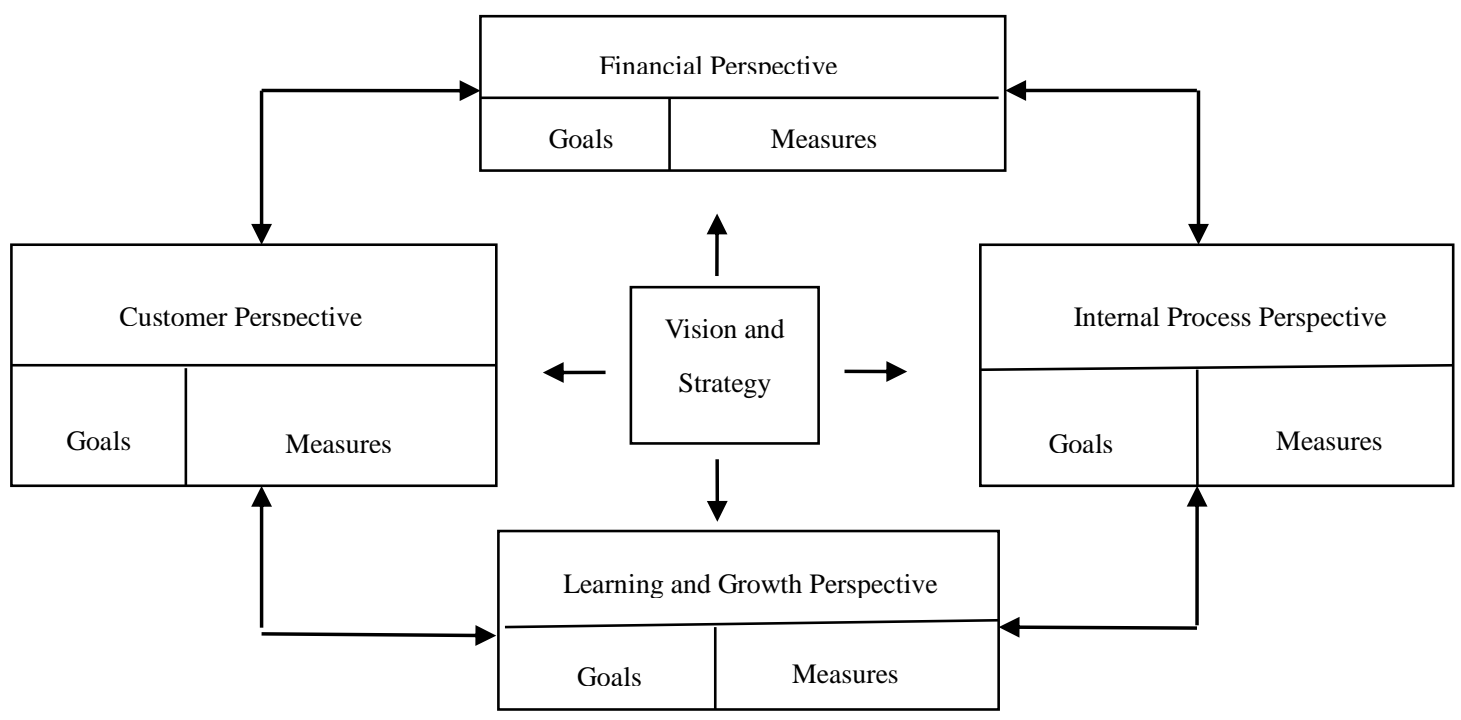

Figure 1. BSC perspectives

Source: Kaplan and Norton (1996b). 
Although the traditional BSC contains four perspectives; i.e., financial, customer, internal processes, and learning and growth, Kaplan and Norton (1996c) stated that the number of perspectives in the BSC is discretionary and one or more additional perspective may be added because this number depending on industry circumstances and a business unit's strategy. Many researchers added one or more additional perspective. Alanati (2004) added "community development service" and "general safety" perspectives to the traditional BSC to measure the performance of Jordanian contracting companies. Maltz et al. (2003) stated that Best Foods added a "people development" perspective to its traditional BSC to emphasize the strategic importance of human resource management. Aljabiri (2005) introduced two perspectives; consideration of compliance with laws and external suppliers, for evaluating the performance in the sector of communications in Jordan. Epstein and Wisner (2001) focused on using a fifth BSC perspective to implement sustainability as a strategic objective. Abufutha (2006) advocated using additional BSC categories to evaluate the performance of Islamic banks in Jordan, which are: "rules of transactions that are consistent with the sharia (Islamic law)" and "control rules and procedures" perspectives. The Nova Chemicals Corporation added a "social" perspective to its BSC to highlight the importance of community (Atkinson \& Epstein, 2001). AL-Khatatneh and Al-Sa'aydeh (2010) discussed using a "company's environment" as a fifth perspective for evaluating strategic performance. Malgwi (2014) demonstrated a modified BSC to assess the cost of insecurity in the North Eastern Nigeria. Van Grembergen and Van Bruggen (1997) adjusted the traditional form of BSC to evaluate IT department. They created four new perspectives: corporate contribution, customer (User) orientation, operational excellence, and future orientation. Chlistalla and Schaper (2009) modified the generic BSC by adding risk management as a separate perspective and by integrating competition and IT. Kim et al. (2014) applied a combined BSC and analytical hierarchy process to better understand web evaluation process. Their modified BSC consists of four perspectives: technical, marketing, customer, and internal perspectives.

\subsection{Environmental Performance Evaluation of Business Organizations}

Environmental performance evaluation is defined by the ISO 14031 (International standards Organization (ISO),1999) as "a process to facilitate management decisions regarding an organization's environmental performance by selecting indicators, collecting and analyzing data, assessing information against environmental performance criteria, reporting and communicating and periodically reviewing and improving this process". According to ISO 14031 environmental performance evaluation indicators can be divided into groups:

- Environmental condition indicators: providing information for organization's external management.

- Environmental performance indicators: providing information for the organization's internal operations. These indicators comprise the management performance indicators and the operational performance indicators.

The report of the United Nations conference on trade and development (United Nations, 1997) established a set of environmental evaluation indicators, which consist of eight domains: the ultimate indicator of environmental impact, emissions and waste indicators, input indicators, resource consumption indicators, efficiency indicators, risk indicator of potential environmental impacts, customer indicators and financial indicators. World Business Council for Sustainable Development (WBCSD) advocated the eco-efficiency indicators to measure the environmental performance of organizations (Verfaillie \& Bidwell, 2000). These indicators are divided into core indicators and secondary indicators. Also, Global Reporting Initiative (GRI) helps organizations understand and communicate the impact of organization on the environment through produce standards for sustainability reporting. The GRI Guidelines set out the guidelines for organizations to measure and report their economic, environmental and social performance (GRI, 2002).

Based on the initiatives of the ISO 14031, the GRI and the eco-efficiency guide of the WBCSD, Kolk and Mauser (2002) classified environmental performance indicators into the following three categories:

- Environmental management indicators: provide information related to the efforts of the management to influence the environmental performance of the organization's operations. These indicators are concerned with the policy, vision, planning activities, practices, procedures, and organizational structure of environmental management.

- Environmental condition indicators: provide information about the direct impacts of the organization's operations on the environment, such as the air, water and soil pollution, ozone layer thickness and global average temperature.

- Environmental performance indicators: They are divided into operational and impact indicators. The operational performance indicators provide information about the environmental performance of specific organization's operations, and related to inputs (materials, natural resources, energy etc.), whereas the impact performance indicators provide information about the outputs of the organizations' operations, and related to products, wastes and emissions resulting from the organization's operations. 
Environmental performance indicators need to satisfy some requirements in order to achieve the desired goals. They need to be relevant to the environmental objectives of the organization and the requirements of stakeholders, and be understandable by non-specialists. Moreover, they should be reliable, comparable in various forms, measurable and verifiable, and be combined with an overall evaluation of organization (Perera et al., 2013).

\subsection{Integration of Environmental Aspects in the Balanced Scorecard}

In response to increasing interest in sustainability, models for sustainability performance evaluation are increasingly being introduced. These models include environmental, social and economic aspects of enterprise performance and address different dimensions of environmental performance (Veleva \& Ellenbecker, 2001; GRI, 2002; Azapagic, 2004). Various studies have proposed a BSC format to incorporate environmental aspects into the strategic performance measurement system (e.g., Figge et al., 2002; Hubbard, 2009; Alewine \& Stone, 2009; Kaplan \& Wisner, 2009). Through the BSC, organizations can delineate the relationship between Sustainability objectives and outcomes with corporate strategy and profitability, e.g., environmental, social, and economic objectives (Butler et al., 2011). On the other hand, an important decision for organizations is how to incorporate environmental aspects in their BSC. Management must decide on the manner in which the environmental aspects will be integrated into its BSC because the presentation of performance indicators is important for performance evaluation and in communicating strategic priorities (Kaplan \& Norton, 2004; Malina \& Selto, 2001). Figge et al. (2002) discussed three Options for integrating environmental aspects in the BSC:

1)- Integrating environmental aspects in the four BSC perspectives: environmental aspects can be subsumed under the four existing BSC perspectives through strategic elements, objectives and indicators. Using this approach, environmental aspects become an integral part of conventional BSC and Integrated within the chain of cause and effect. These aspects should be integrated in the market system. Therefore, this approach is especially relevant for strategic environmental aspects that are already integrated in this system (Figge et al., 2001).

2)- Adding a fifth perspective to the balanced scorecard: Kaplan and Norton pointed out that a company-specific creation of a BSC may involve adding or renaming a perspective. As noted earlier, many environmental aspects are not integrated into a market system as the standard BSC perspectives reflect only the market system. So, adding a fifth perspective (environmental perspective) to the BSC is justified when environmental aspects from outside the market system, consider strategic core aspects of the strategy of the organization.

3)- Developing a separate environmental balanced scorecard: the third approach to including the environmental aspects in the BSC is based on the creation of a separate EBSC in order to be used by the environmental department internally. The design and implementation of a special EBSC have to be connected with a standard BSC. In other words, EBSC is not independent from conventional BSC. With proper linkage with BSC an organization could achieve good results relating environmental management system. Moreover, illustrating the environmental strategy across all four perspectives could help to improve this system (Hockerts, 2001). A separate EBSC is useful as it illustrates links between certain types of environmental performance and the strategic and financial objectives of an organization (Johnson, 1998).

Using a BSC model for evaluating the environmental performance of organizations has been advocated by many researchers. Li and Leigh (2010) developed an EBSC model with identified environmental strategic objectives and illustrated the links of these objectives across different levels in an environmental strategic mapping. Monteiro and Ribeiro (2011) addressed the different possibilities for the integration of environmental issues into the BSC, both in private and public entities. Callaghan et al. (2007) presented a new BSC approach to incorporating stakeholder interests and internal dimensions of the organization with the evaluation of the control environment. Wynder (2013) demonstrated that concern for the environment, perception of ecological risk, and assessment of financial risk, interact with scorecard classification to determine the weighting placed on environmental performance measures. Krivokapic and Jovanovic (2009) focused on an analysis of environmental management system integrated into the classical model of the BSC. They suggested that in this way, organizations could improve environmental performance through the implementation of the strategy. Dias-Sardinha and Reijnders (2005) designed a BSC to evaluate environmental and social performance of 13 large companies operating in Portugal.

\section{Research Methodology}

In order to attain the research aim which is to develop an EBSC to assist organizations in measuring and evaluating their environmental performance, the descriptive analytical approach was adopted for its suitability for the purpose of the study. An initial environmental BSC was developed based on the learning from the literature and relevant documentation regarding environmental standards. The initial proposed EBSC was sent to some managers of the Jordanian share holding companies and academic from reputable business school in 
Jordan. Several modifications have been made to the initial version based on their valuable feedbacks. The finalized EBSC model is presented in section 4.

\section{The Proposed Environmental Balanced Scorecard Model}

A proposed EBSC model is composed of four key perspectives (i.e., financial, customer, internal processes and learning and growth), environmental strategic objectives within each perspective and indicators for measuring and evaluating environmental performance. The suggested EBSC model is presented below.

\section{First: customer perspective}

Objectives: customer satisfaction.

Indicators:

- Degree of response to environmental issues by the organization through the control over the quality of products.

- Degree of effectiveness of the procedures that have been established to protect the environment.

Second: internal process perspective

Objectives:

1)- Existence of an effective environmental control system.

Indicators:

- Number of times of detection a contamination occurrence and given a warning for removing it.

- Number of surprise inspections.

- Reports of environmental control.

- Projects for developing environmental performance.

2)- Quality of workforce.

Indicators:

- The average cost of training an employee.

- The number of prizes obtained by the organization.

3)- Employee satisfaction.

Indicators:

- Number of rewards earned by employees who contribute to development and commitment to the environmental procedures related to the organization's activities.

- Degree of quality and integration of work environment.

\section{Third: learning and growth perspective}

Objectives:

1- Improve the environmental performance strategy.

Indicators:

- Number of training courses related to environmental field.

- Number of participants in training courses related to environmental field.

- Training costs in the environmental field.

2- Achievement general and specific objectives of the organization related to the environmental field.

Indicators:

- Degree of commitment to the laws and public policy requirements.

- Proportion of competition ability of organization to the peer organizations in the same industry.

Fourth: financial perspective

Objectives: reducing environmental costs.

Indicators:

- Proportion of environmental costs to total costs. 
- Proportion of environmental costs to production costs.

- Proportion of environmental costs to sales.

- Proportion of environmental costs to capital.

Figure 2 presents the performance indicators which can be used to evaluate the environmental performance of an organization.

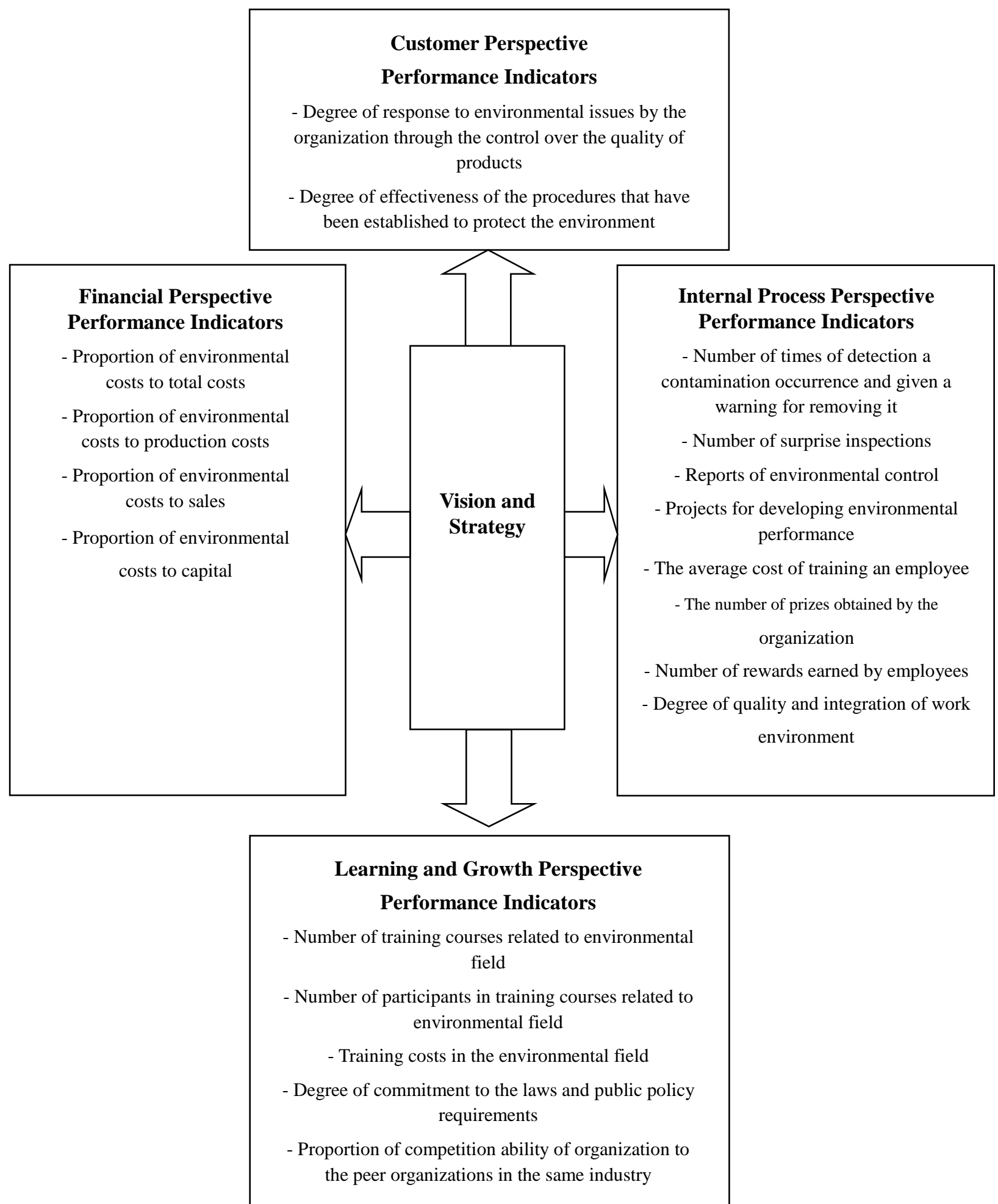

Figure 2. Performance indicators for EBSC 


\section{Summary and Conclusions}

Recently, environmental performance represents a major concern in many organizations. Therefore, a proper evaluation of environmental performance is becoming a requisite of most organizations. Many studies have shown that the BSC is an effective tool to evaluate environmental performance. In this study, an EBSC model was developed to evaluate environmental performance with proposed four perspectives and environmental strategic objectives within each perspective. The four perspectives are the customer, internal process, learning and growth and financial. However, it is necessary to link this scorecard with an already existing BSC. Also, the research highlights alternative methods of integrating environmental aspects in the BSC, which are: integrating environmental aspects in the four BSC perspectives, adding a fifth perspective that focuses on environmental goals and measures, and development of a separate EBSC. The proposed model will help managers not only to evaluate the environmental performance, but also to plan, manage and control organization's environmental activities. In addition, it can serve as a template for the organizations which aims to create environmental awareness and pursue environmental sustainability. Further research is necessary to test the extent of suitability of this proposed model for application by the managers to encourage organizations to consider the adoption of EBSC.

\section{References}

Abufutha, M. A. R. (2006). Towards develop a balanced system to measure strategic performance in Islamic banking institutions (Unpublished Ph.D. Dissertation). Arab Academy for Banking and Financial Sciences, Jordan.

Alanati, R. M. (2004). Building a model for measuring and evaluating performance in contracting companies. Unpublished Ph.D. Dissertation, Amman Arab University, Jordan.

Alewine, H. C., \& Stone, D. N. (2009). How does environmental accounting information influence attention and investment? http://dx.doi.org/10.2139/ssrn.1420883

Algebra, K. R. (2005). Building a model for measuring overall performance in the Jordanian communications sector In light of the global approaches: Japanese, European and American. Unpublished Ph.D. Dissertation, Amman Arab University, Jordan.

AL-Khatatneh, W. R., \& Al-Sa'aydeh, M. (2010). A modified model of the balanced scorecard for the Jordanian public shareholding companies. Dirasat: Administrative Sciences, 37(2), 335-364.

Atkison, A. A., Kaplan, R. S., Matsumura, E. M., \& Young, S. M. (2007). Management accounting (5th ed.). New Jersey: Person Prentice Hall.

Atkison, A., \& Epstein, M. (2001). Measure for measure: Realizing the power of the balanced scorecard. Financial and Management Accounting Committee (FMAC), IFAC.

Azapagic, A. (2004). Developing a framework for sustainable development indicators for the mining and minerals industry. Journal of Cleaner Production, 12(6), 639-662. http://dx.doi.org/10.1016/S0959-6526(03)00075-1

Butler, J. B., Henderson, S. C., \& Raiborn, C. (2011). Sustainability and the balanced scorecard: Integrating green measures into business reporting. Management Accounting Quarterly, 12(2), 1-10.

Callaghan, J. H., Savage, A., \& Mintz, S. (2007). Assessing the control environment using a balanced scorecard approach. The CPA Journal, March, 58-63.

Chlistalla, M., \& Schaper, T. (2009). Modifying the balanced scorecard for a network industry - The case of the clearing industry. In Proceedings of the 9th IFIP Conference on e-Business, e-Services, and e-Society, Nancy, France. http://dx.doi.org/10.1007/978-3-642-04280-5_21

Dias-Sardinha, I., \& Reijnders, L. (2005). Evaluating environmental and social performance of large Portuguese companies: A balanced scorecard approach. Business Strategy and the Environment, 14(2), 73-91. http://dx.doi.org/10.1002/bse.421

Drury, C. (2001). Management accounting for business decisions (2nd ed.). London: Thomson Learning.

Epstein, M. J., \& Wisner, P. S. (2001). Using a balanced scorecard to implement sustainability. Environmental Quality Management, 11(2), 1-10. http://dx.doi.org/10.1002/tqem.1300

Figge, F., Hahn, T., Schaltegger, S., \& Wagner, M. (2001). The sustainability balanced scorecard - A tool for value- oriented sustainability management in strategy-focused organizations. In proceeding of the 2001 Eco-Management and Auditing Conference (pp. 83-90). ERP Environment: Shipley, The Netherlands. 
Figge, F., Hahn, T., Schaltegger, S., \& Wagner, M. (2002). The sustainability balanced scorecard - Linking sustainability management to business strategy. Business strategy and the Environment, 11(5), 269-284. http://dx.doi.org/10.1002/bse.339

GRL. (2002). GRI event organizers sector supplement: Summary guide. Retrieved from https://www.globalreporting.org/resourcelibrary/EOSS-G3.1-SummaryGuide.pdf

Hockerts, K. (2001). Corporate sustainability management - towards controlling corporate ecological and social sustainability. In Proceedings of the Ninths International Conference on Greening of Industry Network (pp. $1-21)$.

Hubbard, G. (2009). Measuring organizational performance: Beyond the triple bottom line. Business Strategy and the Environment, 18(3), 177-191. http://dx.doi.org/10.1002/bse.564

ISO. (1999). ISO 14031: Environmental management - environmental performance evaluation - guidelines. Geneva, Switzerland: ISO.

Johnson, D. S. (1998). Identification and selection of environmental performance indicators: Application of the balanced scorecard approach. Corporate Environmental Strategy, 5(4), 34-41. http://dx.doi.org/10.1016/S1066-7938(00)80079-2

Kaplan, R. S., \& Norton, D. P. (1992). The balanced scorecard-measures that drive Performance. Harvard Business Review, January-February, 71-79.

Kaplan, R. S., \& Norton, D. P. (1993). Putting the balanced scorecard to work. Harvard Business Review, September-October, 134-147.

Kaplan, R. S., \& Norton, D. P. (1996a). Translating strategy into action: The balanced scorecard. Boston: Harvard Business School Press.

Kaplan, R. S., \& Norton, D. P. (1996b). Using the balanced scorecard as a strategic management system. Harvard Business Review, January-February, 1-13.

Kaplan, R. S., \& Norton, D. P. (1996c). The balanced scorecard. Boston, MA: Harvard Business School Press.

Kaplan, R. S., \& Norton, D. P. (2000). Having trouble with your strategy? Then map it. Harvard Business Review, September-October, 167-176.

Kaplan, R. S., \& Norton, D. P. (2004). Strategy maps: Converting intangible assets into tangible outcomes. Boston, MA: Harvard Business School Press.

Kaplan, S. E., \& Wisner, P. S. (2009). The judgmental effects of management communications and a fifth balanced scorecard category on performance evaluation. Behavioral Research in Accounting, 21(2), 37-56. http://dx.doi.org/10.2308/bria.2009.21.2.37

Kim, Y. H., Chung, B., Kwon, K., \& Sukmaungma, S. (2014). The application of the modified balanced scorecard advanced hierarchy process extended to the economy, upscale, and luxury hotels' websites. Anatolia: An International Journal of Tourism and Hospitality Research, 25(1), 81-95. http://dx.doi.org/10.1080/13032917.2013.827128

Kolk, A., \& Mauser, A. (2002). The evolution of environmental management: From stage models to performance evaluation. Business Strategy and the Environment, 11(1), 14-31. http://dx.doi.org/10.1002/bse.316

Krivokapic, Z., \& Jovanovic, J. (2009). Using balanced scorecard to improve environmental management system. Journal of Mechanical Engineering, 55(4), 262-271.

Malgwi, A. A. (2014). Modified balance scorecard assessment of the cost of insecurity in the North Eastern Nigeria. IOSR Journal of Economics and Finance, 3(4), 32-34. https://doi.org/10.9790/5933-0343234

Malina, M. A., \& Selto, F. H. (2001). Communicating and controlling strategy: An empirical study of the effectiveness of the balanced scorecard. Journal of Management Accounting Research, 13(1), 47-90. http://dx.doi.org/10.2308/jmar.2001.13.1.47

Maltz, A. C., Shenhar, A. J., \& Reilly, R. R. (2003). Beyond the balanced scorecard: Refining the search for organizational success measures. Long Range Planning, 36(2), 187-204. http://dx.doi.org/10.1016/S0024-6301(02)00165-6

Monteiro, S. S., \& Ribeiro, V. P. L. (2011). The balanced scorecard as a tool for environmental management: Approaching the business context to the public sector. In Proceedings of the XVIII Brazilian Conference of Costs. Rio de Janeiro, Brazil. Retrieved from 
https://anaiscbc.emnuvens.com.br/anais/article/viewFile/565/565

Perera, P. S. T., Perera, H. S. C., \& Wijesinghe, T. M. (2013). Environmental performance evaluation in supply chain. Vision, 17(1), 53-61. http://dx.doi.org/10.1177/0972262912469566

United Nations. (1997). Trade and development report, United Nations Conference on Trade and Development. Retrieved from http://unctad.org/en/Docs/tdr1997_en.pdf

Van, G. W., \& Van, B. R. (1997). Measuring and improving corporate information technology through the balanced scorecard technique. In Proceedings of the Fourth European Conference on the Evaluation of Information Technology (pp. 163-171). Delft, The_Netherlands.

Veleva, V., \& Ellenbecker, M. (2001). Indicators of sustainable production: framework and methodology. Journal of Cleaner Production, 9(6), 519-549. http://dx.doi.org/10.1016/S0959-6526(01)00010-5

Verfaillie, H. A., \& Bidwell, R. (2000). Measuring eco-efficiency, a guide to reporting company performance. World Business Council for Sustainable Development (WBCSD). Retrieved from http://www.gdrc.org/sustbiz/measuring.pdf

Weygandt, J. J., Kimmel, P. D., \& Kieso, D. E. (2012). Accounting principles (10th ed.). N. J.: John Wiley \& Sons, Inc.

Wynder, M. (2013). Environmental performance as a fifth balanced scorecard perspective: The judgmental effects of environmental concern, perception of ecological risk and perception of financial risk. In Proceedings of RMIT Accounting for Sustainability Conference. Melbourne, Australia. Retrieved from http://mams.rmit.edu.au/dhpwgim0k0y7.pdf

Xiaohong, L., \& Leigh, S. (2010). Integrating environmental management system with environmental performance evaluation across the supply chain: A systematic and balanced scorecard approach. In Proceedings of Knowledge Collaboration and Learning for Sustainable Innovation ERSCP-EMSU Conference (pp. 1-28). Delft, The Netherlands.

\section{Copyrights}

Copyright for this article is retained by the author(s), with first publication rights granted to the journal.

This is an open-access article distributed under the terms and conditions of the Creative Commons Attribution license (http://creativecommons.org/licenses/by/4.0/). 